\title{
Kinerja Lingkungan, Kepemilikan Manajemen, Media Exposure dan Corporate Social Responsibility Disclosure
}

\author{
Ni Wayan Arikarsita ${ }^{1}$ \\ Fakultas Ekonomi dan Bisnis \\ Universitas Udayana, Indonesia
}

\author{
Made Gede Wirakusuma² \\ Fakultas Ekonomi dan Bisnis \\ Universitas Udayana, Indonesia
}

\begin{abstract}
ABSTRAK
Corporate Social Responsibility Disclosure merupakan suatu bentuk tanggung jawab dan komitmen perusahaan dalam hal berkontribusi positif terhadap lingkungan, sosial, dan ekonomi yang diintegrasikan dalam aktivitas perusahaan. Penelitian ini bertujuan untuk memperoleh bukti empiris mengenai pengaruh kinerja lingkungan, kepemilikan manajemen, dan media exposure pada corporate social responsibility disclosure. Penelitian ini dilakukan pada perusahaan manufaktur yang terdaftar di BEI dan terdaftar sebagai peserta PROPER periode 2016-2018. Metode penentuan sampel yang digunakan adalah purposive sampling. Metode pengumpulan data yang digunakan dalam penelitian ini adalah metode observasi non partisipan dan dokumentasi. Penelitian ini menggunakan teknik analisis data berupa analisis regresi linear berganda. Hasil analisis menunjukkan bahwa kinerja lingkungan, kepemilikan manajemen, dan media exposure secara parsial berpengaruh positif pada corporate social responsibility disclosure.
\end{abstract}

Surel : arikarsita73@gmail.com

Kata Kunci: Kinerja Lingkungan; Kepemilikan Manajemen; Media Exposure; Corporate Social Responsibility Disclosure.

\section{Environmental Performance, Management Ownership, Media Exposure and Corporate Social Responsibility Disclosure}

\section{ABSTRACT}

Corporate Social Responsibility Disclosure is a form of corporate responsibility and commitment in making a positive contribution to the environment, social and economy that is integrated in the company's activities. This study aims to obtain empirical evidence regarding the effect of environmental performance, management ownership, and media exposure on corporate social responsibility disclosure. This research was conducted at manufacturing companies listed on the IDX and registered as participants in the 2016-2018 PROPER period. The sampling method used is purposive sampling. Data collection methods used in this study are non-participant observation methods and documentation. This study uses data analysis techniques in the form of multiple linear regression analysis.The analysis shows that environmental performance, management ownership, and media exposure partially have a positive effect on corporate social responsibility disclosure.

Keywords: Environmental Performance; Management Ownership; Media Exposure; Corporate Social Responsibility Disclosure.

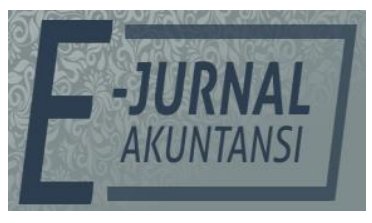

e-ISSN 2302-8556

Vol. 30 No. 12

Denpasar, Desember 2020 Hal. 3096-3109

DOI:

10.24843/EJA.2020.v30.i12.p08

PENGUTIPAN:

Arikarsita, N.W. \&

Wirakusuma, M.G.. (2020).

Kinerja Lingkungan,

Kepemilikan Manajemen, Media Exposure dan Corporate Social Responsibility Disclosure.

E-Jurnal Akuntansi, 30(12), 3096-3109

RIWAYAT ARTIKEL:

Artikel Masuk: 20 Februari 2020 Artikel Diterima: 14 Juli 2020

Artikel dapat diakses : https://ojs.unud.ac.id/index.php/Akuntansi/index 


\section{PENDAHULUAN}

Perkembangan dunia industri yang semakin pesat tentunya berdampak positif terhadap perekonomian Indonesia seperti terjadinya peningkatan Produk Domestik Bruto (PDB), meluasnya peluang kerja bagi masyarakat, serta terpenuhinya kebutuhan akan produk dan jasa. Namun seiring dengan perkembangan tersebut, kebanyakan perusahaan hanya memfokuskan untuk meraih keuntungan semata tanpa memperhatikan lingkungan sekitar dan permasalahan sosial yang mungkin timbul. Perusahaan yang hanya berorientasi pada laba, cenderung hanya mampu memenuhi kebutuhan jangka pendek karena tidak memperhatikan keberlanjutan perusahaan yang bersifat jangka panjang (Vira \& Wirakusuma, 2019). Banyak kasus unjuk rasa yang dilakukan oleh masyarakat sekitar terhadap perusahaan akibat kurang taatnya pengelolaan dan aktivitas perusahaan terhadap peraturan yang berlaku. Berbagai dampak dari keberadaan perusahaan tersebut telah menyadarkan masyarakat bahwa masalah lingkungan merupakan isu yang penting. Hal tersebut menunjukkan bahwa perusahaan juga harus mempertimbangkan faktor non finansial dengan memberikan perhatian kepada lingkungan maupun masyarakat yang terkena dampak dari aktivitas industri, karena faktor finansial saja tidak cukup untuk menjamin keberlanjutan perusahaan (Sabatini \& Sudana, 2019).

Salah satu bentuk perhatian perusahaan terhadap sosial dan lingkungan dapat diwujudkan dengan adanya tanggung jawab sosial perusahaan. Corporate Sosial Responsibility (CSR) merupakan bentuk pemahaman perusahaan akan pentingnya tanggung jawab perusahaan dalam meminimalisir efek negatif yang mungkin timbul dari segala kebijakan dan aktivitas operasional perusahaan. Kewajiban tanggung jawab sosial perusahaan di Indonesia saat ini sudah diatur dalam regulasi pemerintah, seperti yang termuat dalam Peraturan Pemerintah Nomor 47 Tahun 2012 pasal 2. Peraturan terkait CSR juga terdapat dalam Undang-Undang Nomor 25 Tahun 2007 tentang Penanaman Modal pasal 15 huruf $\mathrm{b}$ yang menyatakan bahwa setiap penanam modal memiliki kewajiban untuk melaksanakan tanggung jawab sosial perusahaan. Namun fenomena yang terjadi, meskipun sudah terdapat berbagai regulasi yang mewajibkan pengungkapan CSR, tingkat pengungkapan CSR di Indonesia masih tergolong rendah. Pernyataan tersebut didukung dengan data distribusi per sektor terkait kinerja lingkungan perusahaan yang diukur melalui program penilaian kinerja perusahaan dan pengelolaan lingkungan hidup atau yang biasa disingkat PROPER, dimana data menunjukkan bahwa hampir 50\% dari total peringkat merah diperoleh oleh perusahaan manufaktur. Hal ini menandakan bahwa masih banyak perusahaan yang melanggar standar ketentuan pengelolaan lingkungan hidup. Di sisi lain, industri manufaktur merupakan salah satu industri yang aktivitasnya banyak melibatkan sumber daya alam maupun sumber daya manusia. Hal ini menandakan bahwa kepedulian perusahaan terhadap lingkungan masih perlu ditingkatkan (Alshbili et al., 2019).

Sejalan dengan konsep sustainable development goals, parameter keberhasilan suatu perusahaan dilihat dari perilaku moral dan etis dimana dalam pencapaian tujuan perusahaan tidak boleh merugikan kelompok masyarakat lainnya (Wahyutama, 2016). Hal ini sejalan dengan teori stakeholder bahwa perusahaan tidak hanya mengejar keuntungan semata, tetapi juga harus 
mampu memberikan manfaat kepada stakeholdernya (Syed \& Butt, 2017). Berbagai upaya telah dilakukan oleh pemerintah untuk meningkatkan pengungkapan CSR oleh perusahaan, salah satunya dengan menyelenggarakan Program Penilaian Peringkat Kinerja Perusahaan dalam Pengelolaan Lingkungan Hidup (PROPER). Penghargaan PROPER akan mendorong perusahaan untuk taat terhadap peraturan lingkungan hidup. Penilaian PROPER dilakukan dengan sistem pemeringkatan dari terbaik hingga terburuk dengan pemberian warna yaitu emas, hijau, biru, merah, dan hitam.

Pelaksanaan CSR juga tidak bisa terlepas dari penerapan Good Corporate Governance (GCG) yang mencerminkan prinsip responsibility untuk memastikan kesesuaian pengelolaan perusahaan dengan peraturan perundang-undangan yang berlaku (Widyastari \& Ratna Sari, 2018). Salah satu faktor good corporate governance yang berpengaruh pada pelaksanaan CSR adalah struktur kepemilikan manajemen. Kepemilikan manajemen adalah persentase kepemilikan saham yang dimiliki oleh direksi, manajer dan dewan komisaris. Sejalan dengan teori keagenan, bahwa dalam hubungan antara pihak agen dan prinsipal kemungkinan terjadi konflik kepentingan. Semakin besar kepemilikan manajer di dalam perusahaan maka semakin produktif tindakan manajer dalam memaksimalkan nilai perusahaan, dengan kata lain biaya kontrak dan pengawasan menjadi rendah (Permadiswara \& Sujana, 2018).

Penelitian-penelitian mengenai kinerja lingkungan dan kepemilikan manajemen terhadap Pengungkapan CSR telah banyak dilakukan, namun belum menunjukkan konsistensi hasil. Penelitian mengenai pengaruh struktur GCG dan kinerja lingkungan terhadap pengungkapan CSR yang dilakukan oleh Sukasih \& Sugiyanto (2017) mendapatkan hasil bahwa kepemilikan institusional dan kepemilikan manajerial memiliki pengaruh pada pengungkapan corporate social responsibility, namun berpengaruh negatif. Sementara penelitian lain yang dilakukan oleh Handayati (2017) dalam penelitian yang berjudul Analisis Kinerja Lingkungan dan Mekanisme GCG Terhadap Pengungkapan Pertanggungjawaban Sosial, mendapatkan hasil bahwa variabel kinerja lingkungan, ukuran dewan komisaris, komite audit berpengaruh positif signifikan terhadap corporate social responsibility disclosure (CSRD). Sedangkan variabel kepemilikan institusional dan dewan komisaris independen tidak berpengaruh terhadap CSRD. Sehingga peneliti ingin meneliti kembali terkait pengaruh kinerja lingkungan dan kepemilikan manajemen terhadap CSRD.

Peneliti menambahkan variabel media exposure serta memperbarui tahun pengamatan yaitu periode 2016-2018 dengan tujuan kebaruan data serta supaya hasil penelitian dapat lebih digeneralisasi. Pemilihan media exposure sebagai salah satu variabel independen di karenakan media memiliki peran yang sangat penting di zaman teknologi yang semakin berkembang. Perusahaan tidak hanya dituntut untuk melakukan kegiatan CSR dengan baik, tetapi juga harus memiliki kemampuan untuk mengkomunikasikan tanggung jawab tersebut kepada para stakeholder (Pakpahan \& Rajagukguk, 2018). Dalam hal mendapatkan kepercayaan dan legitimasi melalui kegiatan CSR, maka perusahaan harus mempunyai kapasitas untuk berkomunikasi dengan para pemangku kepentingan secara efektif (Prasethiyo, 2017). Penelitian Respati \& Hadiprajitno (2015), A.P \& Hardiningsih (2015), dan Hasnia \& Rofingatun (2017) menyatakan 
bahwa media exposure berpengaruh positif terhadap pengungkapan CSR. Hal ini berarti media exposure merupakan salah satu faktor yang diduga mempengaruhi indeks pengungkapan CSR.

Sampel yang digunakan dalam penelitian ini adalah perusahaan manufaktur yang terdaftar di BEI dan terdaftar sebagai peserta PROPER, yang terdiri dari sektor industri barang konsumsi, sektor industri dasar dan kimia, dan sektor aneka industri. Jika dilihat dari segi peluang, industri manufaktur memiliki prospek yang baik dan cenderung meningkat setiap tahunnya. Industri manufaktur memiliki peran penting dan merupakan salah satu penggerak perekonomian Indonesia. Berdasarkan data yang dipublikasi pada tahun 2016 oleh United Nations Statistics Division, Indonesia menduduki peringkat keempat dari 15 negara di dunia dimana industri manufaktur mampu berkontribusi lebih dari 10 persen terhadap Produk Domestik Bruto (PDB). Namun jika dilihat dari segi risiko terhadap lingkungan, industri manufaktur memiliki tingkat produksi yang tinggi serta limbah produksi yang dihasilkan tentunya dalam jumlah yang tidak sedikit, sehingga pengungkapan CSR memegang peranan penting agar masyarakat mengetahui sejauh mana perusahaan melakukan tanggung jawab sosialnya. Dalam skala produksi yang tinggi tersebut, perusahaan juga didukung oleh tenaga kerja yang erat kaitannya dengan masalah kesejahteraan dan keselamatan pekerja (Permana, 2012). Selain itu, seiring meningkatnya kebutuhan masyarakat akan produk dan jasa, maka memicu tumbuhnya industri-industri baru. Lebih lanjut, pemerintah memiliki target untuk mengikutsertakan industri-industri manufaktur dalam ajang internasional. Oleh karena itu isu CSR menjadi isu yang penting. Memang pertumbuhan industri tersebut mempunyai dampak positif terhadap perekonomian Indonesia, namun diperlukan perhatian dan pengawasan yang cukup serius agar pengembangan industri tetap memperhatikan kelestarian lingkungan serta sesuai dengan peraturan yang berlaku.

Penelitian ini bertujuan untuk memperoleh bukti empiris mengenai pengaruh kinerja lingkungan, kepemilikan manajemen, dan media exposure pada corporate social responsibility disclosure. Hasil dari penelitian ini diharapkan dapat memberikan kontribusi dalam kajian dan pengembangan teori-teori yang relevan, diantaranya teori legitimasi, teori stakeholder, dan teori keagenan. Penelitian ini juga dapat dijadikan sebagai salah satu sumber informasi bagi pihak manajemen dalam hal mengelola faktor-faktor yang dapat memengaruhi efektivitas pengungkapan CSR sehingga dapat meminimalisir ketimpangan informasi yang mungkin terjadi dan dapat mempertahankan keberlangsungan perusahaan.

Kinerja lingkungan diukur dari prestasi perusahaan mengikuti Program Penilaian Peringkat Kinerja Perusahaan dalam Pengelolaan Lingkungan Hidup (PROPER). PROPER diumumkan secara rutin kepada masyarakat, sehingga masyarakat dapat menilai tingkat ketaatan perusahaan terhadap lingkungan. Sukasih \& Sugiyanto (2017) menyatakan bahwa semakin baik aktivitas lingkungan yang dilakukan oleh perusahaan, maka akan meningkatkan kepercayaan dimata stakeholder. Penelitian Handayati (2017) berhasil menunjukkan hubungan yang positif antara kinerja lingkungan dan 
pengungkapan tanggung jawab sosial. Berdasarkan uraian tersebut maka perumusan hipotesis sebagai berikut.

$\mathrm{H}_{1}$ : Kinerja lingkungan berpengaruh positif pada corporate social responsibility disclosure.

Mc Williams \& Siegel (2018) dalam penelitiannya menyatakan bahwa sejalan dengan teori keagenan, penyebab konflik yang mungkin timbul antara manajer dan pemegang saham adalah kepemilikan manajer yang kecil di perusahaan tersebut. Ketika kepemilikan manajemen semakin besar, manajer tidak akan mengambil tindakan yang merugikan perusahaan, sehingga dapat mengurangi biaya agensi. Salah satunya melalui pengungkapan informasi sosial yang seluas-luasnya. Berdasarkan uraian tersebut, maka perumusan hipotesis sebagai berikut.

$\mathrm{H}_{2}$ : Kepemilikan manajemen berpengaruh positif pada corporate social responsibility disclosure.

Media exposure merupakan salah satu proksi dari tekanan publik, karena media exposure memiliki peran dalam membentuk opini masyarakat (Michelon, 2011). Adanya media exposure yang lebih intensif akan meningkatkan visibilitas perusahaan yang akan memengaruhi pandangan publik terhadap suatu hal (Tan, et al., 2016). Jika suatu perusahaan berada di bawah pengawasan publik, maka akan muncul upaya untuk membangun citra positif perusahaan. Pengungkapan CSR merupakan salah satu upaya yang dilakukan perusahaan dalam meningkatkan reputasi perusahaan. Penelitian yang dilakukan oleh Respati \& Hadiprajitno (2015) berhasil menunjukkan hubungan yang positif antara media exposure dengan pengungkapan CSR. Hal tersebut juga didukung dengan penelitian yang dilakukan oleh Hasnia \& Rofingatun (2017) serta penelitian Permadiswara \& Sujana (2018) yang menunjukkan media exposure memiliki pengaruh positif pada pengungkapan tanggung jawab sosial. Berdasarkan uraian tersebut maka perumusan hipotesis sebagai berikut.

$\mathrm{H}_{3}$ : Media exposure berpengaruh positif pada corporate social responsibility disclosure.

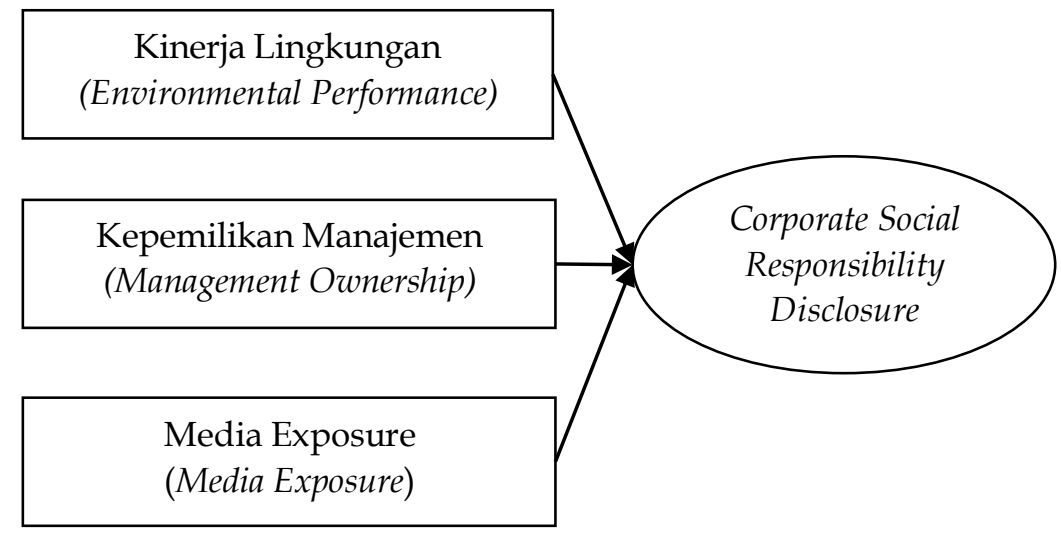

Gambar 1. Model Penelitian

Sumber: Data Penelitian, 2020

\section{METODE PENELITIAN}

Penelitian dilakukan pada situs resmi Bursa Efek Indonesia (BEI) yaitu www.idx.co.id, dengan mengunduh laporan tahunan perusahaan manufaktur 
yang terdaftar di Bursa Efek Indonesia pada tahun 2016-2018. Obyek penelitian dalam penelitian ini adalah corporate social responsibility disclosure oleh perusahaan manufaktur yang terdaftar di Bursa Efek Indonesia tahun 2016-2018 melalui data laporan tahunan perusahaan.

Corporate Social Responsibility Disclosure (CSRD) merupakan suatu komitmen perusahaan untuk memberikan kontribusi positif kepada lingkungan, sosial, dan masyarakat yang diintegrasikan dalam pengelolaan perusahaan (Yuliyanti, 2019). Pengungkapan CSR diukur menggunakan Corporate Social Responsibility Disclosure Index (CSRDI) berdasarkan pedoman Global Reporting Initiatives (GRI) versi G4 dengan jumlah indikator 91 item pengungkapan. Terdapat dua jenis nilai yang digunakan, yaitu nilai 1 jika indikator diungkapkan dalam pelaporan dan nilai 0 jika tidak ada pengungkapan. Kemudian jumlah item tersebut akan dihitung dengan formula sebagai berikut (Rengganis \& Putri, 2018).

$$
\mathrm{CSRDI}_{j}=\frac{\sum x i j}{N j}
$$

Keterangan:

$\mathrm{CSRDI}_{j}=$ Corporate Social Responsibility Disclosure Index perusahaan $\mathrm{j}$

$\sum \mathrm{X}_{\mathrm{ij}} \quad=$ Jumlah indikator yang diungkapkan perusahaan $\mathrm{j}$

$\mathrm{N}_{\mathrm{j}} \quad$ = Jumlah indikator yang seharusnya diungkapkan $\mathrm{j}, \mathrm{Nj}=91$

Kinerja lingkungan adalah kinerja perusahaan dalam menciptakan lingkungan sekitar yang baik (Wijaya \& Nuryatno, 2019). Kinerja lingkungan perusahaan dapat diukur melalui PROPER yang diterbitkan oleh Kementerian Lingkungan Hidup (KLH). PROPER menggunakan 5 kategori yang ditunjukkan dengan warna-warna sebagai bentuk peringkat perusahaan. Peringkat tersebut diantaranya emas, hijau, biru, merah, dan hitam. Warna emas merupakan peringkat tertinggi dan diikuti dengan warna hijau, biru, merah, dan hitam sebagai kategori terburuk. Penelitian ini menggunakan data ordinal yaitu pengukuran kinerja dalam bentuk skor 1 hingga 5, uraiannya sebagai berikut:

\section{Tabel 1. Penilaian Peringkat PROPER}

\begin{tabular}{ll}
\hline Warna & Nilai \\
\hline Emas & 5 \\
Hijau & 4 \\
Biru & 3 \\
Merah & 2 \\
Hitam & 1 \\
\hline
\end{tabular}

Sumber: Bahri \& Cahyani, 2017

Kepemilikan manajemen adalah jumlah lembar saham pihak manajemen (manajer, direksi, dan komisaris terafiliasi) yang dibandingkan dengan jumlah lembar saham yang beredar. Sehingga, formulasi untuk kepemilikan manajemen adalah sebagai berikut.

$\mathrm{KM}=\frac{\text { Jumlah saham yang dimiliki manajemen }}{\text { Jumlah saham yang beredar }}$

Media exposure adalah pemanfaatan media yang tersedia untuk mengkomunikasikan identitas serta informasi atas aktivitas yang dilakukan oleh perusahaan (Respati \& Hadiprajitno, 2015). Konsisten dengan penelitian Permadiswara \& Sujana (2018), dimana media exposure diukur dengan menggunakan variabel dummy, yaitu memberikan nilai 1 untuk perusahaan 
yang mengkomunikasikan kegiatan CSR di website perusahaan dan memberikan nilai 0 untuk perusahaan yang tidak mengungkapkan kegiatan CSR di website perusahaan.

Jenis data yang digunakan dalam penelitian ini adalah data kuantitatif, yaitu data berupa angka atau data kualitatif yang diangkakan serta dapat dinyatakan dalam satuan hitung (Sugiyono, 2016b). Data kuantitatif yang digunakan dalam penelitian ini adalah laporan tahunan pada perusahaan manufaktur yang terdaftar di Bursa Efek Indonesia periode 2016-2018 yang mencakup jumlah item pengungkapan CSR, peringkat PROPER, dan struktur kepemilikan saham perusahaan. Sumber data yang digunakan dalam penelitian ini adalah data sekunder. Data sekunder merupakan sumber data yang memberikan data secara tidak langsung kepada pengumpul data, seperti melalui perantara orang lain maupun dalam bentuk dokumen (Sugiyono, 2016:156). Penelitian ini menggunakan data sekunder yang diperoleh dari laporan tahunan perusahaan manufaktur di Bursa Efek Indonesia tahun 2016-2018 yang diunduh pada situs resmi www.idx.co.id.

Populasi dalam penelitian ini adalah seluruh perusahaan manufaktur yang terdaftar di Bursa Efek Indonesia periode 2016-2018. Sampel dalam penelitian ini ditentukan menggunakan metode purposive sampling, yaitu metode pengumpulan sampel atas dasar kriteria tertentu untuk menghindari adanya bias akibat perbedaan yang signifikan. Adapun kriteria dalam penelitian ini antara lain: Perusahaan manufaktur yang terdaftar di Bursa Efek Indonesia (BEI) pada periode 2016-2018; Perusahaan manufaktur yang menyajikan annual report atau laporan tahunan secara berturut-turut selama periode 2016-2018; Perusahaan manufaktur yang terdaftar sebagai peserta PROPER secara berturut-turut pada tahun 2016-2018.

Metode pengumpulan data dalam penelitian ini adalah menggunakan metode observasi non-participant yaitu observasi tanpa melibatkan diri dan hanya sebagai pengamat independen (Sugiyono, 2016:167). Teknik analisis data dalam penelitian ini menggunakan teknik Regresi Linear Berganda dan diolah menggunakan alat statistik SPSS. Adapun tahapan analisis dimulai dari statistik deskriptif, uji asumsi klasik, analisis regresi berganda, koefisien determinasi, uji kelayakan model serta uji hipotesis.

Dalam penelitian ini teknik analisis regresi linier berganda digunakan untuk mengetahui pengaruh variabel independen berupa kinerja lingkungan, kepemilikan manajemen, dan media exposure pada variabel dependen yaitu corporate social responsisibility disclosure. Persamaan regresi tersebut adalah sebagai berikut:

$$
Y=\alpha+\beta_{1} X_{1}+\beta_{2} X_{2}+\beta_{3} X_{3}+\varepsilon
$$

Keterangan :

$\mathrm{Y}=$ Corporate Social Responsibility Disclosure

a $\quad=$ Konstanta

$\beta_{1}-\beta_{3}=$ Koefisien regresi

$\mathrm{X}_{1} \quad=$ Kinerja lingkungan

$\mathrm{X}_{2} \quad=$ Kepemilikan manajemen

$\mathrm{X}_{3}=$ Media exposure

$\varepsilon \quad=$ Tingkat kesalahan penduga pada penelitian 
HASIL DAN PEMBAHASAN

Penelitian ini dimaksudkan untuk mengetahui apakah kinerja lingkungan, kepemilikan manajemen, dan media exposure berpengaruh pada corporate social responsibility disclosure. Sampel yang digunakan dalam penelitian ini dipilih secara purposive sampling, sehingga sampel yang digunakan dapat menjelaskan populasi yang dimaksudkan. Selanjutnya dilakukan pemilihan data sekunder berdasarkan kriteria pemilihan sampel yang telah ditentukan.

Tabel 2. Proses Pemilihan Sampel

\begin{tabular}{ll}
\hline Kriteria & Jumlah Perusahaan \\
\hline Jumlah seluruh perusahaan manufaktur yang terdaftar di BEI & 133 \\
periode 2016-2018 & \\
Jumlah perusahaan yang tidak mengikuti PROPER & $(101)$ \\
Jumlah perusahaan yang tidak mengungkapkan kepemilikan & $(14)$ \\
manajemen & \\
Total perusahaan yang diteliti & 18 \\
Total pengamatan 2016-2018 & 54 \\
Data outlier & - \\
Total pengamatan akhir & 54
\end{tabular}

Sumber: Data Penelitian, 2017

Lokasi dalam penelitian ini adalah perusahaan manufaktur yang terdaftar di Bursa Efek Indonesia (BEI) periode 2016-2018 yang didapatkan dengan cara mengakses website resmi www.idx.co.id. Berdasarkan data pada Tabel 2, terdapat 18 perusahaan manufaktur yang terdaftar di BEI pada tahun 2016-2018 yang sesuai dengan kriteria pemilihan sampel, sehingga terdapat 54 sampel dalam tiga tahun periode pengamatan.

Analisis statistik deskriptif penelitian menjelaskan mengenai karakteristik variabel-variabel penelitian yang terdiri dari jumlah pengamatan, nilai minimum, nilai maksimum, nilai rata-rata dan standar deviasi. Tabel 3, berikut menunjukkan hasil analisis statistik deskriptif variabel penelitian ini.

Tabel 3. Statistik Deskriptif

\begin{tabular}{llllll}
\hline & $\mathrm{N}$ & Minimum & Maximum & Mean & Std. Deviation \\
\hline Kinerja Lingkungan & 54 & 2 & 4 & 3.15 & .529 \\
Kepemilikan Manajemen & 54 & .0007 & .3434 & .060265 & .0296427 \\
Media Exposure & 54 & 0 & 1 & .72 & .452 \\
CSRD & 54 & .3626 & .6044 & .471926 & .0282482 \\
Valid N (listwise) & 54 & & & & \\
\hline
\end{tabular}

Sumber: Data Penelitian, 2020

Variabel Kinerja lingkungan diukur sesuai dengan peringkat PROPER yang diperoleh perusahaan berdasarkan keputusan Kementerian Lingkungan Hidup diperoleh rata-rata sebesar 3,15 (pembulatan menjadi 3) atau jika dikonversi sesuai dengan peringkat PROPER yaitu berada pada kategori warna biru yang berarti rata-rata perusahaan telah mengupayakan pengelolaan lingkungan sesuai dengan peraturan yang berlaku. Nilai minimum untuk skor terendah sebesar 2,00 serta nilai maksimum untuk perolehan skor tertinggi yaitu sebesar 4,00. Nilai standar deviasi sebesar 0,529 dimana lebih kecil dari nilai rata- 
rata sebesar 3,15 sehingga menunjukkan penyebaran data normal dan tidak mengakibatkan bias.

Variabel kepemilikan manajemen diukur dengan cara membandingkan jumlah saham yang dimiliki manajemen dengan jumlah saham yang beredar. Hasil uji statistik deskriptif menunjukkan nilai minimum sebesar 0,0007 dan nilai maksimum sebesar 0,3434. Nilai standar deviasi sebesar 0,0296427 lebih kecil dari nilai rata-rata sebesar 0,060265 menunjukkan hasil bahwa penyebaran data adalah normal.

Variabel media exposure menunjukkan nilai minimum sebesar 0 yaitu perusahaan yang tidak mengkomunikasikan aktivitas CSR di website resmi perusahaan, dan nilai maksimum sebesar 1 yaitu perusahaan-perusahan yang mengkomunikasikan aktivitas CSRnya di website resmi perusahaan. Nilai standar deviasi sebesar 0,452 lebih kecil dari nilai rata-rata sebesar 0,72 menunjukkan bahwa penyebaran data normal.

Variabel CSRD menunjukkan nilai paling rendah sebesar 0,3626 yiatu perusahaan dengan kode INDS dan nilai paling tinggi sebesar 0,6044 yaitu perusahaan dengan kode SIDO. Nilai rata-rata corporate social responsibility disclosure sebesar 0,471926 yang menunjukkan bahwa pengungkapan CSR pada perusahaan manufaktur masih tergolong rendah. Nilai standar deviasi sebesar 0,0282482 yang lebih kecil dari nilai rata-rata menunjukkan bahwa data terhindar dari bias.

Selanjutnya dilakukan uji asumsi klasik untuk memastikan bahwa model atau persamaan yang diuji tidak melanggar asumsi tersebut. Hasil uji normalitas pada menunjukkan bahwa nilai Asymp. Sig (2-tailed) sebesar 0,798 dimana lebih besar dari tingkat signifikansi, yaitu 0,05 atau 5 persen yang berarti bahwa residual memiliki distribusi normal. Kemudian didapatkan bahwa nilai VIF dan Tolerance sesuai dengan dasar pengambilan keputusan yaitu tidak terdapat nilai Tolerance yang kurang dari 0,1 dan tidak terdapat nilai VIF yang lebih besar dari 10. Oleh karena itu dapat disimpulkan bahwa pada model analisis tidak ditemukan adanya gejala multikolinearitas. Uji autokorelasi menggunakan uji Durbin-Watson (DW), dan didapatkan nilai Durbin-Watson pada penelitian ini sebesar 1,822 yang sesuai dengan kriteria $d u<D W<4$-du sehingga model regresi terbebas dari autokorelasi. Uji heteroskedastisitas pada penelitian ini menggunakan uji Glejser. Berdasarkan hasil uji yang didapatkan yaitu Kinerja Lingkungan $\left(X_{1}\right)$ memiliki nilai signifikansi sebesar 0,079, Kepemilikan Manajemen $\left(\mathrm{X}_{2}\right)$ sebesar 0,860 dan Media Exposure $\left(\mathrm{X}_{3}\right)$ sebesar 0,626. Nilai signifikansi masing-masing variabel tersebut lebih besar dari $a=0,05$. Sehingga hal ini berarti tidak terjadi gejala heteroskedastisitas.

Berdasarkan hasil yang tertera pada Tabel 4, maka dirumuskan persamaan sebagai berikut.

$$
\mathrm{Y}=0,173+0,052 \mathrm{X}_{1}+0,311 \mathrm{X}_{2}+0,029 \mathrm{X}_{3}
$$

Nilai konstanta sebesar 0,173 menunjukkan bahwa ketika kinerja lingkungan, kepemilikan manajemen, dan media exposure adalah sama dengan nol, maka besarnya corporate social responsibility disclosure adalah 0,173 dengan asumsi variabel lainnya adalah konstan. Nilai koefisien $\beta_{1}=0,052$. Hasil ini menunjukkan bahwa jika kinerja lingkungan meningkat atau bertambah satu satuan, maka akan meningkatkan corporate social responsibility disclosure sebesar 
0,052 dengan asumsi variabel lainnya konstan. Nilai koefisien $\beta_{2}=0,311$. Hasil ini menunjukkan bahwa jika kepemilikan manajemen meningkat atau bertambah satu satuan, maka akan meningkatkan corporate social responsibility disclosure sebesar 0,311 dengan asumsi variabel lain adalah konstan. Nilai koefisien $\beta_{3}=$ 0,029 . Hasil ini menunjukkan bahwa jika media exposure meningkat atau bertambah satu satuan, maka akan meningkatkan corporate social responsibility disclosure sebesar 0,029 dengan asumsi variabel lain adalah konstan.

Analisis regresi linear berganda menggunakan software SPSS 16 for Windows. Hasil analisis dapat dilihat pada Tabel 4, berikut.

Tabel 4. Hasil Analisis Regresi Linear Berganda

\begin{tabular}{|c|c|c|c|c|c|c|}
\hline \multirow{2}{*}{\multicolumn{2}{|c|}{ Model }} & \multicolumn{2}{|c|}{$\begin{array}{l}\text { Unstandardized } \\
\text { Coefficients }\end{array}$} & $\begin{array}{l}\text { Standardized } \\
\text { Coefficients }\end{array}$ & \multirow[b]{2}{*}{$\mathrm{t}$} & \multirow[b]{2}{*}{ Sig. } \\
\hline & & $\mathrm{B}$ & $\begin{array}{l}\text { Std. } \\
\text { Error }\end{array}$ & Beta & & \\
\hline 1 & (Constant) & .173 & .017 & & 10.502 & .000 \\
\hline & $\begin{array}{l}\text { Kinerja } \\
\text { Lingkungan }(X 1)\end{array}$ & .052 & .008 & .552 & 6.495 & .000 \\
\hline & $\begin{array}{l}\text { Kepemilikan } \\
\text { Manajemen (X2) }\end{array}$ & .311 & .057 & .457 & 5.417 & .000 \\
\hline & $\begin{array}{l}\text { Media Exposure } \\
(\mathrm{X} 3)\end{array}$ & .029 & .012 & .203 & 2.347 & .023 \\
\hline
\end{tabular}

Sumber: Data Penelitian, 2020

Uji kelayakan model regresi (Uji F) dimaksudkan untuk mengetahui apakah semua variabel bebas yang diidentifikasi yaitu kinerja lingkungan, kepemilikan manajemen, dan media exposure tepat digunakan memprediksi Corporate Social Responsibility Disclosure. Nilai P value 0,000 pada hasil uji F yang lebih kecil dari $a=0,05$, menunjukkan bahwa model yang digunakan dalam penelitian ini adalah layak. Untuk menguji kemampuan model dalam hal menjelaskan variasi variable independen, maka digunakan uji koefisien determinasi. Hasil uji menunjukkan bahwa nilai adjusted $\mathrm{R}^{2}$ sebesar 0,644. Ini memiliki arti bahwa variasi Corporate Social Responsibility Disclosure pada perusahaan manufaktur periode 2016-2018 dipengaruhi secara signifikan oleh variabel Kinerja Lingkungan, Kepemilikan Manajemen, dan Media Exposure sebesar 64,4\% dan sisanya 35,6\% dipengaruhi oleh faktor-faktor lainnya.

Pengujian hipotesis pertama menunjukkan hasil bahwa kepemilikan manajemen memiliki pengaruh positif pada corporate social responsibility disclosure. Kinerja lingkungan dicerminkan oleh prestasi perusahaan terkait pengelolaan lingkungan hidup yang kemudian dinilai dalam ajang PROPER. Masyarakat dapat mengetahui sejauh mana tanggung jawab perusahaan melalui informasi peringkat PROPER. Sukasih \& Sugiyanto (2017) menyatakan bahwa kepercayaan stakeholder akan meningkat seiring dengan semakin baiknya aktivitas lingkungan oleh perusahaan. Penelitian ini konsisten dengan penelitian Handayati (2017) yang berhasil menunjukkan hubungan yang positif antara kinerja lingkungan dan corporate social responsibility disclosure.

Pengujian hipotesis kedua menunjukkan hasil bahwa kepemilikan manajemen berpengaruh positif pada corporate social responsibility disclosure. 
Kepentingan manajer selaku pengelola perusahaan akan dapat berbeda dengan kepentingan pemegang saham. Konflik kepentingan antara manajer dengan pemilik menjadi semakin besar ketika kepemilikan manajer terhadap perusahaan semakin kecil. Sebaliknya, semakin besar kepemilikan manajer di dalam perusahaan maka semakin produktif tindakan manajer dalam memaksimalkan nilai perusahaan, dengan kata lain biaya kontrak dan biaya pengawasan menjadi rendah. Manajer perusahaan akan mengungkapkan informasi sosial dalam rangka untuk meningkatkan image perusahaan, meskipun ia harus mengorbankan sumber daya untuk aktivitas tersebut (Anggraini, 2006). Penelitian ini konsisten dengan penelitian Sila Prakasa (2018) yang berhasil menunjukkan hubungan yang positif antara kepemilikan manajemen dan corporate social responsibility disclosure.

Pengujian hipotesis ketiga menunjukkan hasil bahwa media exposure memiliki pengaruh positif pada corporate social responsibility disclosure. Perusahaan akan mengungkapan CSR lebih luas ketika aktivitas CSRnya dipublikasikan pada website resmi perusahaan. Paparan media berperan penting dalam penyampaian informasi kepada masyarakat dan mampu menggiring pandangan masyarakat terhadap perusahaan. Penelitian ini menunjukkan hasil yang sama dengan penelitian sebelumnya yang diteliti oleh (Reverte 2009) serta (Respati \& Hadiprajitno 2015). Media exposure melalui website resmi perusahaan akan memberikan kesempatan kepada para pemangku kepentingan untuk berdialog secara langsung dengan perusahaan sehingga perusahaan akan meningkatkan transparansi melalui pengungkapan aktivitas sosial dan lingkungan. Media juga berperan penting bagi stakeholder khususnya bagi investor dan kreditur dalam hal pengambilan keputusan, sehingga secara tidak langsung media turut mempengaruhi keberlangsungan perusahaan.

Berdasarkan hasil pembahasan dapat disimpulkan bahwa kinerja lingkungan, kepemilikan manajemen dan media exposure memiliki pengaruh positif pada corporate social responsibility disclosure. Hal tersebut mampu membuktikan teori legitimasi dan teori stakeholder bahwa perusahaan akan melakukan pengungkapan informasi yang dinilai memiliki respon positif dari stakeholders dengan melakukan pengungkapan CSR untuk dapat diterima di masyarakat sehingga mampu mempertahankan eksistensi perusahaan. Untuk mendapatkan kepercayaan serta legitimasi maka perusahaan akan melakukan pengungkapan tanggung jawal sosial seluas-luasnya. Selain mempunyai kewajiban untuk melakukan aktivitas CSR dengan sungguh-sungguh, perusahaan juga dituntut untuk mampu mengkomunikasikan kegiatannya secara efektif kepada para pemangku kepentingan melalui media sehingga kebutuhan informasi para stakeholders terpenuhi.

Kepemilikan manajemen dalam penelitian ini juga mampu mendukung teori keagenan yang menjelaskan bahwa kepemilikan manajer yang semakin kecil terhadap perusahaan akan meningkatkan konflik kepentingan antara pemilik dan manajer. Sebaliknya, semakin besar kepemilikan manajer di dalam perusahaan maka semakin produktif tindakan manajer dalam memaksimalkan nilai perusahaan, dengan kata lain biaya kontrak dan biaya pengawasan menjadi rendah. Manajer perusahaan akan mengungkapkan informasi sosial dalam 
rangka untuk meningkatkan image perusahaan, meskipun ia harus mengorbankan sumber daya untuk aktivitas tersebut.

Hasil penelitian ini menunjukkan bahwa secara empiris kinerja lingkungan, kepemilikan manajemen dan media exposure dapat dijadikan referensi bagi pihak manajemen dalam mengambil keputusan terkait corporate social responsibility disclosure. CSRD juga berperan penting untuk menarik minat calon investor karena mampu meningkatkan reputasi perusahaan. CSR merupakan investasi perusahaan demi pertumbuhan dan keberlanjutan, sehingga bukan lagi dilihat sebagai biaya melainkan sarana dalam meraih keuntungan. Perusahaan yang memperhatikan CSR tentunya memperhatikan keberlanjutan perusahaan ke depannya.

\section{SIMPULAN}

Berdasarkan penjelasan hasil analisis, maka diperoleh simpulan sebagai berikut: 1) Kinerja lingkungan berpengaruh positif pada corporate social responsibility disclosure. Kinerja lingkungan yang semakin baik tentunya mendorong perusahaan untuk melakukan pengungkapan tanggung jawab sosial yang lebih luas. 2) Kepemilikan manajemen berpengaruh positif corporate social responsibility disclosure. Semakin besar kepemilikan manajemen maka semakin produktif tindakan manajer dalam memaksimalkan nilai perusahaan melalui pengungkapan aktivitas sosialnya. 3) Media exposure berpengaruh positif pada corporate social responsibility disclosure. Adanya media exposure akan mendorong perusahaan untuk mengkomunikasikan aktivitas CSR di website resminya sehingga akan meningkatkan indeks CSR.

Berdasarkan simpulan yang telah diuraikan, maka dapat disampaikan beberapa saran sebagai berikut: 1) Peneliti selanjutnya dapat mempertimbangkan untuk memperluas sampel penelitian yaitu seluruh perusahaan yang terdaftar di Bursa Efek Indonesia serta dapat mengganti atau menambah variabel independen lainnya untuk menyempurnakan penelitian ini. 2) Manajemen perusahaan sebaiknya mempertimbangkan faktor-faktor yang memengaruhi corporate social responsibility disclosure sehingga dapat mengambil keputusan pengungkapan aktivitas sosial dengan tepat serta kebutuhan informasi para stakeholders dapat terpenuhi. 3) Investor sebaiknya mempertimbangkan variabel kinerja lingkungan, kepemilikan manajemen, dan media exposure sebagai tambahan informasi terkait keputusan investasi.

\section{REFERENSI}

A.P, W. P., \& Hardiningsih, P. (2015). Pengaruh Agresivitas Pajak Dan Media Eksplosure Terhadap Corporate Social Responsibility. Dinamika Akuntansi, Keuangan Dan Perbankan.

Alshbili, I., Elamer, A. A., \& Beddewela, E. (2019). Ownership Types, Corporate Governance and Corporate Social Responsibility Disclosures: Empirical Evidence From a Developing Country. Accounting Research Journal. https:/ / doi.org/10.1108/ARJ-03-2018-0060

Bahri, S., \& Cahyani, F. A. (2017). Pengaruh Kinerja Lingkungan Terhadap Corporate Financial Performance Dengan Corporate Social Responsibility Disclosure Sebagai Variabel I Ntervening (Studi Empiris Pada Perusahaan 
Manufaktur Yang Terdaftar Di Bei). Ekonika: Jurnal Ekonomi Universitas Kadiri. https://doi.org/10.30737/ekonika.v1i2.11

Handayati, P. (2017). Analisis Kinerja Lingkungan dan Mekanisme GCG terhadap Pengungkapan Pertanggungjawaban Sosial. Jurnal Akuntansi Aktual. https://doi.org/10.17977/um004v4i12017p058

Hasnia, \& Rofingatun, S. (2017). Pengaruh Profitabilitas, Likuiditas, Growth dan Media Exposure terhadap Pengungkapan Tanggung Jawab Sosial Perusahaan (Studi Empiris pada Perusahaan Manufaktur dan Perusahaan Jasa yang Terdaftar di Bursa Efek Indonesia Tahun 2013-2015). Jurnal Akuntansi $\mathcal{E}$ Keuangan Daerah. Retrieved from http:// ejournal.akuntansiuncen.ac.id/index.php/JurnalAkuntansiUncen/a rticle/view/26

Mc Williams, A., \& Siegel, D. (2018). Corporate Social Responsibility: A Theory of the Firm Perspective. In Business Ethics and Strategy, Volumes I and II. https://doi.org/10.4324/9781315261102-8

Michelon, G. (2011). Sustainability Disclosure and Reputation: A Comparative Study. Corporate Reputation Review. https:// doi.org/10.1057/crr.2011.10

Pakpahan, Y., \& Rajagukguk, L. (2018). Analisis Pengaruh Profitabilitas, Ukuran Perusahaan, Ukuran Dewan Komisaris, dan Media Exposure Terhadap Pengungkapan Tanggung Jawab Sosial. JURNAL AKUNTANSI, 18(2).

Permadiswara, K. Y., \& Sujana, I. K. (2018a). Pengaruh Profitabilitas, Ukuran Perusahaan, Kepemilikan Manajemen dan Media Exposure Pada Pengungkapan Corporate Social Responsibility. E-Jurnal Akuntansi, 25, 690. https:// doi.org/10.24843/eja.2018.v25.i01.p26

Permadiswara, K. Y., \& Sujana, I. K. (2018b). Pengaruh Profitabilitas, Ukuran Perusahaan, Kepemilikan Manajemen dan Media Exposure Pada Pengungkapan Corporate Social Responsibility. E-Jurnal Akuntansi. https:// doi.org/10.24843/eja.2018.v25.i01.p26

Permana, B. A. (2012). Analisis Tingkat Kesehatan Bank Berdasarkan Metode CAMELS dan Metode RGEC. Jurnal Akuntansi Unesa. Retrieved from https://jurnalmahasiswa.unesa.ac.id/index.php/jurnalakuntansi/article/view/288/212

Prasethiyo, D. (2017). Pengaruh leverage, Ukuran Perusahaan, Sensitivitas Industri, dan Media Exposure Terhadap Pengungkapan Tanggung Jawab Sosial Perusahaan. Journal of Personality and Social Psychology. https:// doi.org/10.1111/j.1469-7610.2010.02280.x

Rengganis, R. M. Y. D., \& Putri, I. G. A. M. A. D. (2018). Pengaruh Corporate Governance dan Pengungkapan Corporate Social Responsibility Terhadap Agresivitas Pajak. E-Jurnal Akuntansi Universitas Udayana, 24(2), 871-898. https:// doi.org/https:/ / doi.org/10.24843/EJA.2018.v24.i02.p03

Respati, R. D., \& Hadiprajitno, P. B. (2015). Analisis Pengaruh Profitabilitas, Leverage, Ukuran Perusahaan, Tipe Industri, Dan Pengungkapan Media Terhadap Pengungkapan Corporate Social Responsibility. Diponegoro Journal of Accounting. Retrieved from https://ejournal3.undip.ac.id/index.php/accounting/article/view/9587

Reverte, C. (2009). Determinants of Corporate Social Responsibility Disclosure Ratings by Spanish Listed Firms. Journal of Business Ethics. 
https:// doi.org/10.1007/s10551-008-9968-9

Sabatini, K., \& Sudana, I. P. (2019). Pengaruh Pengungkapan Corporate Social Responsibility Pada Nilai Perusahaan Dengan Manajemen Laba Sebagai Variabel Moderasi. Jurnal Ilmiah Akuntansi Dan Bisnis. https://doi.org/10.24843/jiab.2019.v14.i01.p06

Sugiyono. (2016a). Metode Penelitian Pendidikan (Kuantitatif Kualitatif dan R \& D). In Bandung: Alfabeta. https:// doi.org/10.1164/rccm.200409-1267OC

Sugiyono. (2016b). Skala Pengukuran dan Instrumen Penelitian. Metode Penelitian Kuantitatif, Kualitatif, Dan RED.

Sukasih, A., \& Sugiyanto, E. (2017). Pengaruh Struktur Good Corporate Governance dan Kinerja Lingkungan Terhadap Pengungkapan Corporate Social Responsibility (Studi Pada Perusahaan Manufaktur di Bursa Efek Indonesia Periode 2011-2015). Riset Akuntansi Dan Keuangan Indonesia. https:// doi.org/10.23917/reaksi.v2i2.4894

Syed, M. A., \& Butt, S. A. (2017). Financial and Non-Financial Determinants of Corporate Social Responsibility: Empirical Evidence from Pakistan. Social Responsibility Journal. https:// doi.org/10.1108/SRJ-08-2016-0146

Tan, A., Benni, D., \& Liani, W. (2016). Determinants of corporate social responsibility disclosure and investor reaction. International Journal of Economics and Financial Issues. Retrieved from https://econjournals.com/index.php

Vira, A. N., \& Wirakusuma, M. G. (2019). Pengaruh Pengungkapan Corporate Social Responsibility Pada Nilai Perusahaan Dengan Good Corporate Governance Sebagai Pemoderasi. E-Jurnal Akuntansi. https:// doi.org/10.24843/eja.2019.v26.i02.p17

Wahyutama. (2016). Pengaruh Ukuran Perusahaan , Profitabilitas , Leverage , dan Media Exposure Terhadap Corporate Social Responsibility Disclosure. Artikel Ilmiah Mahasiswa, 1-8. Retrieved from http:// repository.unej.ac.id/handle/123456789/76422

Widyastari, N. K. W., \& Ratna Sari, M. M. (2018). Pengaruh Ukuran Perusahaan, Proporsi Dewan Komisaris Independen, dan Kepemilikan Asing pada Pengungkapan Corporate Social Responsibility. E-Jurnal Akuntansi. https:// doi.org/10.24843/EJA.2018.v22.i03.p07

Wijaya, B. A., \& Nuryatno, M. (2019). Pengaruh Environmental Performance dan Enviromental Disclosure Terhadap Economic Performance. Jurnal Informasi, Perpajakan, Akuntansi, Dan Keuangan Publik. https:// doi.org/10.25105/jipak.v9i2.4530

Yuliyanti, L. (2019). Pengaruh Good Corporate Governance dan Pengungkapan Corporate Social Responsibility Terhadap Nilai Perusahaan. Jurnal Pendidikan Akuntansi Dan Keuangan. https:// doi.org/10.17509/jpak.v2i2.15464 